\title{
PENGGUNAAN TEKNIK PICTURE-CUED UNTUK MENINGKATKAN KETERAMPILAN BERBICARA BAHASA INGGRIS
}

\author{
Retno Dwigustini ${ }^{1}$, Baiatun Nisa ${ }^{{ }^{*}}$, Susilawati ${ }^{2}$, Uung Hodijah ${ }^{2}$ \\ ${ }^{1}$ Fakultas Komunikasi dan Bahasa, Universitas Bina Sarana Informatika \\ ${ }^{2}$ Program Studi Pendidikan Bahasa Inggris, STKIP Kusuma Negara \\ *baiatun nisa@bsi.ac.id
}

Received: January $08^{\text {th }}, 2021$

Revised: March 22 $2^{\text {rd }}, 2021$

Accepted: May $25^{\text {th }}, 2021$

\section{ABSTRACT}

The research aimed at improving students' speaking skill using picture-cued technique. Classroom action research with 3 cycles was employed. The research subject consisted of 20 students of tenth grade. The technique of data collection consisted of observation, test and interview. The finding signified that the students' speaking skill is improved. In cycle I, only $70 \%$ of students passed the passing grade. In cycle 2, 90\% passed the grade and in cycle 3, 100\% passed the grade. The significant of this research did not only explore about picture-cued technique but also identified students' response of the application of picture-cued technique in English speaking learning. The result of the research showed students' positive responses to the use of the technique. This further means that the implementation of picture-cued is successful in enhancing students' speaking skill.

Keywords: English speaking skill; picture-cued technique; speaking skills

\section{PENDAHULUAN}

Berbicara dalam bahasa Inggris terlebih lagi di era Revolusi Industri ini merupakan hal yang sangat krusial untuk dikuasai oleh siswa. Keterampilan ini bisa membawa siswa untuk membuka komunikasi dengan orang asing baik untuk kehidupan pribadi, keperluan akademik maupun dalam kaitannya dengan dunia kerja di masa depan. Seperti yang disebutkan dalam laporan yang dirilis oleh The British Council (2013), keterampilan dalam berbahasa Inggris akan berpengaruh pada kehidupan personal individu dan dunia profesi. Lembaga ini bahkan mengatakan bahwa kemampuan berkomunikasi dalam bahasa Inggris mampu mengubah kehidupan seseorang dari segi sosial, ekonomi dan budaya. Terlebih lagi, dalam konteks pendidikan bahasa Inggris di Indonesia yaitu dengan penggunaan Kurikulum 2013, disebutkan bahwa siswa diharuskan untuk mampu 
berbicara dengan bahasa Inggris sesuai dengan fungsi sosial dan tujuan komunikatif yang ditargetkan sebagai bentuk adaptasi dari pembelajaran berbasis-wacana atau genre.

Namun sayangnya, pembelajaran untuk meningkatkan keterampilan berbicara ini masih menghadapi sejumlah kendala. Masalah yang dianggap paling mendasar adalah kurangnya kosakata siswa dan pengucapan yang kurang tepat (Heriansyah, 2012; Rahayu, 2015). Motivasi dan kurangnya tingkat kepercayaan diri untuk berbicara pun seringkali menghambat siswa untuk berbicara dalam bahasa Inggris (Al Nakhalah, 2014). Oleh karena itu, diperlukan teknik yang mampu merangsang dan menantang siswa untuk lebih banyak berbicara secara komunikatif.

Di sisi lain, dibutuhkan media dan teknik yang tepat untuk membantu siswa meningkatkan kemampuan membaca (Dayarni, 2020). Salah satu teknik yang dipercaya mampu meningkatkan keterampilan siswa dalam berbicara adalah picture-cued. Teknik ini diimplementasikan dengan menyediakan sejumlah kartu bergambar bagi siswa kemudian siswa diminta mendeskripsikan secara lisan apa yang mereka lihat dalam kartu tersebut, di mana teknik ini mampu (Brown, 2004). Picture-cued ini dianggap bisa memberikan stimulan untuk interaksi dan spontanitas siswa dalam komunikasi lisan yang sesungguhnya (Littlewood, 1981). Teknik ini sudah secara empiris terbukti mampu meningkatkan keterampilan siswa dalam berbicara. Penelitian yang dilakukan oleh Fujiono dan Khairuddin (2018) membuktikan bahwa teknik picture-cued sukses membantu meningkatkan keterampilan berbicara siswa dengan tingkat kesuksesan 84,37\%. Simamora et al. (2018) juga membuktikan bahwa teknik picture-cued ini mampu meningkatkan keterampilan berbicara siswa dilihat dari kenaikan nilai bsrbicara yang cukup signifikan. Temuan penelitian Andhini et al. (2019) secara empiris telah membuktikan bahwa teknik picture-cued ini memberikan efek yang positif terhadap keterampilan berbicara siswa. Lebih spesifiknya, tenik ini terbukti mampu meningkatkan produksi kata (Petit, 2019).

Penelitian-penelitian yang dilakukan untuk mengeksplorasi penggunaan teknik picture-cued ini umumnya menyoroti performance dan nilai siswa setelah belajar dengan menggunakan teknik ini. Respon siswa terhadap penggunaan 
teknik belajar ini belum banyak disorot. Karenanya, selain membahas hasil belajar, penelitian ini pun difokuskan untuk mengidentifikasi bagaimana siswa merespon penerapan teknik picture-cued.

\section{METODE PENELITIAN}

Penelitian ini bertujuan untuk mengetahui peningkatan kemampuan berbicara siswa dengan menggunakan teknik picture-cued. Penelitian yang dilakukan pada semester dua tahun akademik 2019/2020 ini menggunakan pendekatan kualitatif dengan disain penelitian tindakan kelas atau Classroom Action Research. Penelitian tindakan dipahami sebagai satu penelitian dalam situasi sosial saat guru meningkatkan rasionalitas dan penilaian atas praktik mengajar mereka melalui refleksi diri (Carr \& Kemmis, 1986; Komara, Putra, \& Hermita, 2020; Lestari, Hermita, \& Kurniaman, 2019). Penelitian ini dilakukan dalam empat langkah: merencanakan, mengumpulkan data, menganalisis, dan merefleksikan.

Disain penelitian ini melibatkan 20 siswa dari kelas $X$ di sebuah SMA swasta di daerah Jakarta sebagai subjek penelitian. Data dikumpulkan melalui observasi, tes dan wawancara. Penelitian dilaksanakan dalam 3 siklus dengan setiap siklus terdiri dari perencanaan, pelaksanaan, pengamatan, dan refleksi. Observasi dilaksanakan selama pembelajaran berlangsung dan tes diberikan diberikan dalam bentuk post-test kepada siswa di setiap akhir siklus. Sementara wawancara dilakukan di akhir pelaksanaan siklus 3 dengan teknik group interview seperti yang disarankan oleh Cresswell (2012). Data yang didapat kemudian dianalisis dengan mengadaptasi teori dari Miles, Huberman, \& Saldana (2014) yang terdiri dari reduksi, penyajian dan verifikasi data. Data yang didapat dari hasil observasi, tes dan wawancara kemudian dikonfirmasi dengan menggunakan teknik triangulasi. 


\section{HASIL PENELITIAN}

\section{Implementasi dan Peningkatan Keterampilan Berbicara Siswa}

\section{Siklus 1}

Tahap perencanaan di siklus 1 dimulai dengan mempersiapkan RPP (Rencana Pelaksanaan Pembelajaran) berdasarkan silabus dan standar kompetensi Kurikulum 2013. Topik yang diambil pada siklus ini adalah bagianbagian badan.

Tahap pelaksanaan pembelajaran terdiri dar kgiatan pembuka, kegiatan inti, dan kegiatan penutup. Teknik picture-cued ini diaplikasikan secara berkelompok. Pada kegiatan pembuka, siswa bermain tebak gambar sebagai kegiatan awal yang memiliki tujuan membantu siswa mempersiapkan diri terhadap pembelajaran. Pada kegiatan inti, siswa diminta untuk mendeskripsikan fungsi anggota badan sesuai gambar yang mereka dapatkan dalam kelompok masing masing. Para siswa diminta berdiskusi kemudian mempresentasikan gambar dengan mengunakan beberapa kalimat secara lisan. Pada kegiatan penutup, siswa mendapat beberapa pertanyaan yang berhubungan dengan anggota tubuh, dimana kegiatan penutup memiliki fungsi untuk mengevaluasi sejauh mana kemampuan siswa dalam menyerap materi yang diberikan.

Selama proses pengamatan, peneliti mengobservasi kegiatan siswa dan keaktifan mereka dalam kegiatan tersebut. Terlihat bahwa sejumlah siswa masih belum berpartisipasi aktif dan terlihat ragu-ragu ketika berbicara. Kelompok siswa yang seharusnya berdiskusi, hanya beberapa siswa yang aktif, sedangkan Sebagian siswa masih pasif dan terlihat kurang percaya diri.

Setelah kegiatan pembelajaran selesai, siswa diberi posttest untuk melihat sejauh mana teknik picture-cued membantu peningkatan keterampilan berbicara mereka. Posttest yang diberikan dalam bentuk lisan, masing masing siswa diminta untuk mempresentasikan anggota tubuh dari gambar yang siswa pilih. Hasilnya menunjukkan belum semua siswa mencapai KKM (Kriteria Ketuntasan Minimal). Hanya 70\% siswa berhasil mencapai KKM, sementara 30\% lainnya mendapat skor di bawah KKM. Hampir semua aspek keterampilan berbicara masih perlu ditingkatkan. 


\section{Siklus 2}

Siklus 2 diawali dengan merencanakan RPP yang indikatornya disesuaikan dengan hasil refleksi siklus 1 . Topik yang disajikan kepada siswa di siklus 2 ini adalah tentang jenis-jenis pekerjaan. Aspek-aspek berbicara yang diamati masih kurang di siklus 1 menjadi perhatian utama pada siklus 2 ini.

Dalam pelaksanaannya, pada kegiatan pembuka, siswa diberikan beberapa gambar secara acak, kemudian siswa dibagi menjadi beberapa kelompok untuk menggabungkan gambar gambar tersebut menjadi satu kesatuan gambar bercerita. Pada kegiatan inti siswa diminta untuk menjelaskan jenis profesi yang mereka lihat di gambar. Siswa dibagi menjadi beberapa kelompok, kemudian siswa berdiskusi berdasarkan gambar profesi yang mereka peroleh. Ada kelompok yang memperoleh gambar profesi pendidikan, ada kelompok lain yang memperoleh profesi seni, dan ada yang memperoleh profesi kesehatan. Para siswa berdiskusi mengenai profesi-profesi tersebut, mereka diminta untuk menjelaskan nama profesi, tugas profesi dan nama nama terkenal dalam dunia profesi tersebut. Setelah mereka berdiskusi, ada perwakilan siswa yang maju kedepan untuk mempresentasikan secara lisan dengan menggunakan gambar profesi tersebut.

Hasil pengamatan selama kegiatan pembelajaran berlangsung menunjukkan bahwa keterampilan berbicara mereka mulai menunjukkan perbaikan. Siswa mulai lancar berbicara dengan menggunakan kosakata dengan pengucapan yang cukup baik. Mereka juga mulai nampak percaya diri ketika berbicara.

Perbaikan ini terbukti dari hasil posttest yang dilakukan setelah selesainya pembelajaran. Post-test yang diberikan dalam bentuk lisan, masing masing siswa diminta untuk mempresentasikan sebuah profesi dari gambar yang siswa pilih. Hampir 90\% siswa mampu melampaui KKM dengan nilai rata-rata 75,65, sementara $10 \%$ lainnya masih membutuhkan peningkatan.

\section{Siklus 3}

Di siklus 3, peneliti merencanakan untuk membahas topik bangunan bersejarah. Topik ini dipilih mengingat siswa membutuhkan materi dengan tingkat kesulitan di atas materi siklus 2 . 
Pada pelaksanaan kegiatan pembuka, siswa sudah mulai aktif dan berani berbicara. Kegiatan pembuka di siklus ini, siswa melakukan tebak gambar. Ada satu siswa yang duduk didepan kelas dengan mata ditutup. Ada gambar bangunan yang ditempel dipapan tulis. Siswa lain memberikan petunjuk berupa beberapa kalimat yang berhubungan dengan gambar tersebut, dan siswa yang ditutup matanya harus menebak gambar pakah itu. Para siswa menampakkan antusiasme ketika melakukan kegiatan ini. Pada pelaksanaan kegiatan inti, siswa mendapatkan gambar bangunan bersejarah. Siswa terbagi menjadi beberapa kelompok. Siswa berdiskusi membahasa mengenai nama bangunan, berada di daerah mana, berdiri pada tahun berapa dan mengapa bangunan tersebut merupakan bangunan bersejarah. Setelah para siswa berdiskusi, mereka diminta maju ke depan untuk mempresentasikan bangunan bersejarah dengan menunjukan gambar yang mereka peroleh. Selama tahap pelaksanaan, terlihat siswa hampir semuanya menunjukkan perbaikan. Hampir semua aspek berbicara mereka sudah terlatih dan mereka lebih percaya diri ketika berbicara.

Di akhir pembelajaran, siswa diberikan posttest terakhir. Dalam post-test ini masing masing siswa diminta untuk mempresentasikan bangunan bersejarah dari gambar yang siswa pilih. Hasilnya terlihat memuaskan karena 100\% siswa mampu melewati KKM dengan nilai rata-rata 83,25.

Untuk membandingkan hasil ketuntasan belajar yang diperoleh di setiap siklus, berikut disajikan hasil post-test peningkatan keterampilan berbicara dalam bahasa Inggris dengan teknik Picture-Cued pada masing-masing siklus.

Tabel 1. Hasil Post-Test Peningkatan Keterampilan Berbicara dalam Bahasa Inggris dengan Teknik Picture-Cued

\begin{tabular}{|l|c|c|c|}
\hline $\begin{array}{c}\text { Hasil Post-Test dalam Peningkatan } \\
\text { Keterampilan Berbicara dalam Bahasa } \\
\text { Inggris dengan Teknik Picture-Cued }\end{array}$ & Siklus 1 & Siklus 2 & Siklus 3 \\
\hline Nilai Kriteria Ketuntasan Minimal (KKM) & 75 & 75 & 75 \\
\hline Nilai Rata-rata Post-Test & 63,1 & 75,65 & 83,25 \\
\hline $\begin{array}{l}\text { Nilai Persentase Siswa dengan } \\
\text { Peningkatan Keterampilan Berbicara }\end{array}$ & $70 \%$ & $90 \%$ & $100 \%$ \\
\hline
\end{tabular}


Tabel 1 menunjukkan bahwa nilai siswa mengalami peningkatan sejak siklus 1 hingga siklus 3 . Semua aspek keterampilan berbicara yang terdiri dari struktur, kosakata, pemahaman, kelancaran dan pengucapan mengalami kenaikan yang signifikan hingga melampau nilai minimum yang ditetapkan.

\section{PEMBAHASAN PENELTIAN}

Hasil penelitian ini membuktikan teknik picture-cued mampu meningkatkan keterampilan berbicara siswa. Temuan ini sejalan dengan sejumlah penelitian relevan terdahulu. Riswanto (2015) secara statistik membuktikan bahwa teknik picture-cued mempengaruhi peningkatan kemampuan berbicara siswa sekolah menengah pertama. Lavalle \& Briesmaster (2017) melakukan penelitian serupa dengan subjek selevel dan menemukan pengaruh yang juga signifikan dari picture-cued terhadap keterampilan berbicara. Lebih spesifik lagi, penelitian Berliana (2012) telah membuktikan bahwa penggunaan picture-cued membantu siswa meningkatkan aspek kemampuan berbicara siswa yaitu konten, pemahaman, kelancaran pengucapan, kosakata dan struktur.

\section{Respon Siswa}

Berdasarkan hasil wawancara yang dilakukan setelah pelaksanaan teknik picture-cued, siswa-siswa menunjukkan respon yang positif terhadap penggunaan teknik ini. Hal ini terlihat dari hasil wawancara siswa yang mengatakan: "Belajar bahasa Inggris dengan menggunakan picture-cued membuat membuat belajar lebih menyenangkan dan percaya diri untuk berbicara". Respon lain yang diungkapkan siswa dalam belajar bahasa Inggris dengan teknik picture-cued adalah: "kata-kata baru yang dipelajari dengan menggunakan picture-cued membantu lebih mudah untuk diingat, dipahami, dan dilafalkan". Lebih lanjut, siswa lain juga mengungkapkan: "Picture-cued membuat lebih percaya diri karena membantu mengucapkan kosa kata baru dengan pengucapan dan intonasi dengan benar". Pernyataan siswa ini sejalan dengan pendapat Berliana (2012) yang menyatakan bahwa teknik picture-cued dinilai bisa menciptakan atmosfer pembelajaran yang menyenangkan bagi siswa. 
Dari hasil respon siswa dapat diketahui bahwa: 1) siswa menyatakan bahwa teknik ini menarik karena menciptakan pembelajaran yang menyenangkan. Siswa juga merasa bahwa penggunaan teknik ini membantu memperkaya kosakata mereka. Manfaat yang dirasakan siswa ini sesuai dengan apa yang diungkapkan oleh (Thornbury, 2004) bahwa gambar merupakan cara terbaik untuk memperkenalkan kosakata baru atau untuk menghubungkan kata yang abstrak dengan gambaran mentalnya; 2) mereka juga mengakui bahwa teknik ini membantu mereka untuk memperbaiki pengucapan kosakata karena mereka harus berbicara dengan tekanan dan intonasi yang tepat. Hal ini juga sudah pernah dibuktikan sebelumnya oleh Lavalle \& Briesmaster (2017) bahwa penggunaan picture-cued ini dinilai siswa bisa meningkatkan dan memperbaiki pengucapan bahasa Inggris siswa sekolah menengah pertama yang menjadi subjek penelitian mereka; 3) penggunaan teknik ini juga diakui siswa mampu memotivasi dan meningkatkan kemampuan berbicara dalam bahasa Inggris sehingga kepercayaan diri mereka juga dirasa meningkat. Hal ini sejalan dengan teori yang dikemukakan oleh (Zainatuddar, 2015) dan (Thornbury, 2004) bahwa pembelajaran dengan gambar akan memberikan motivasi meningkatkan kemampuan berbicara bahasa Inggris.

\section{SIMPULAN}

Hasil dan pembahasan penelitian ini menunjukkan bahwa teknik picturecued mampu meningkatkan keterampilan berbicara siswa terbukti dengan kenaikan skor dari siklus 1 ke siklus 3 di mana semua siswa mampu melampaui KKM. Semua aspek keterampilan berbicara yakni struktur, kosakata, pemahaman, kelancaran dan pengucapan mengalami kenaikann yang memuaskan.

Berdasarkan hasil post-test, 70\% siswa telah berhasil mencapai nilai KKM menunjukkan, kemudian terdapat $20 \%$ peningkatan pada siklus 2 . Ini membuat persentase siswa yang mencapai nilai KKM menjadi 90\%. Pada siklus 3, 100\% dari seluruh siswa sudah meningkat keterampilan berbicaranya dalam bahasa Inggris dengan penggunaan teknik picture-cued.

Selain peningkatan keterampilan berbicara, siswa memberikan respon positif terhadap penggunaan teknik picture-cued karena teknik ini dianggap 
menarik, mampu memperkaya kosakata siswa sekaligus memperbaiki pengucapannya. Selain itu, teknik picture-cued juga memotivasi dan menaikkan kepercayaan diri siswa untuk lebih banyak berbicara dalam bahasa Inggris.

Hasil penelitian ini merekomendasikan bahwa siswa harus diberikan stimulan yang lebih banyak agar bisa berbicara dalam bahasa Inggris dengan lancar. Bagi peneliti selanjutnya, disarankan juga untuk menggunakan media gambar yang lebih bervariatif misalnya penggunaan gambar multimedia yang relevan dengan perkembangan teknologi di era digital ini.

\section{DAFTAR PUSTAKA}

Al Nakhalah, A. M. M. (2014). Problems and difficulties of speaking that encounter English language students at AI Quds Open University. International Journal of Humanities and Social Science Invention, 5(12), 96-101.

Andhini, A., Dahnilsyah, D., \& Marzuki, M. (2019). The effect of using picture-cued storytelling technique on the speaking ability of the third year students of SMPN 8. JOM FKIP, 6(1-9).

Berliana, E. (2012). Improving students' speaking skills in VIII A class of SMP BOPKRI II Yogyakarta by using picture-cued technique: classroom action research. Sanata Dharma University.

Brown, H. D. (2004). Language assessment: Principles and classroom practices. New York: Pearson Education.

Carr W \& Kemmis S 1986.Becoming Critical: Education, Knowledge And Action Research. London: The Falmer Press.

Cresswell, J. W. (2012). Educational research: Planning, conducting, and evaluating quantitative and qualitative research (4th ed.). Boston.: Pearson.

Dayarni. (2020). Permainan Scrabble untuk Meningkatkan Kemampuan Membaca Awal Siswa Kelas 1 SDN 002 Belakang Padang Kota Batam. Lectura: Jurnal Pendidikan, $11(2)$ 270-281.

https://doi.org/https://doi.org/10.31849/lectura.v11i2.4753

Fujiono, F., \& Khairuddin, K. (2018). Penggunaan teknik picture cued storytelling untuk meningkatkan kemampuan speaking siswa kelas XI-IPA di MA Miftahul Ulum Bettet Pamekasan. DIDAKTIKA : Jurnal Pemikiran Pendidikan, 24(2), 150. https://doi.org/10.30587/didaktika.v24i2.335

Heriansyah, H. (2012). Speaking problems faced by the English department students of Syiah Kuala University. Lingua Didaktika, 6(1), 37-44.

Komara, F. H. T., Putra, Z. H., \& Hermita, N. (2020). Penerapan model 
pembelajaran kooperatif tipe picture and picture untuk meningkatkan hasil belajar matematika siswa kelas IVB SDN 136 Pekanbaru. Tunjuk Ajar: Jurnal $\begin{array}{llllll}\text { Penelitian IImu Pendidikan, } & 3(2), & 146 & - & 162 .\end{array}$ http://dx.doi.org/10.31258/jta.v3i2.146-162

Lavalle, P., \& Briesmaster, M. (2017). The study of the use of picture descriptions in enhancing communication skills among the 8th- grade students--learners of English as a foreign language. I.e.: Inquiry in Education, 9(1), 1-16.

Lestari, W. I. S., Hermita, N., \& Kurniaman, O. (2019). Application Of PAIKEM GEMBROT Learning Model to Improve Fifth Graders' Science Learning Motivation. Journal of Teaching and Learning in Elementary Education, 2(2), $164-173$.

Littlewood, W. (1981). Communicative language teaching. Cambridge University Press.

Miles, M. B., Huberman, A. M., \& Saldana, J. (2014). Qualitative data analysis: A methods sourcebook. Sage Publications, Inc.

Petit, M. C. (2019). Picture cued and speech production cued approaches for speech sound learning. Louisiana State University and Agricultural and Mechanical College.

Mathematical Literacy Skills of Fifth Grade Elementary School Students: A Case Study in Pekanbaru. Journal of Teaching and Learning in Elementary Education, 4(1), 39 -50.

Rahayu, N. (2015). An analysis of students 'problems in speaking English daily language program at Husnul Khotimah Islamic Boarding School. UIN Syekh Nurjati.

Riswanto, A. (2015). The effect of picture cued to the seventh grade students' speaking ability of SMP Islam Sejahtera Badas in the academic year 2017/2018. Universitas Nusantara PGRI Kediri.

Simamora, J. M., Sembiring, N., \& Pangaribuan, J. J. (2018). Improving students' speaking skills by using picture-cued media to the eighth grade students of SMP Santo Yoseph Medan. Kairos ELT Journal, 2(2), 111-127.

The British Council. (2013). The English effect. Retrieved from https://www.britishcouncil.org/sites/default/files/english-effect-report-v2.pdf

Thornbury, S. (2004). How to teach vocabulary (1st ed.). Pearson Education Limited.

Zainatuddar, B. (2015). Teaching Speaking in English by Using the Picture Series Technique. English Education Journal (EEJ), 6(4), 443-456. Retrieved from http://www.jurnal.unsyiah.ac.id/EEJ/article/view/2854 